\title{
Teacher Discrimination Reduces School Performance of African American Youth: Role of Gender
}

\author{
Shervin Assari 1,2,3,*(D) and Cleopatra Howard Caldwell 2,4 \\ 1 Department of Psychiatry, University of Michigan, Ann Arbor, MI 48109, USA \\ 2 Center for Research on Ethnicity, Culture and Health, University of Michigan School of Public Health, \\ Ann Arbor, MI 48109, USA; cleoc@umich.edu \\ 3 Department of Psychology, University of California Los Angeles (UCLA), Los Angeles, CA 90095, USA \\ 4 Department of Health Behavior and Health Education, University of Michigan School of Public Health, \\ Ann Arbor, MI 48109, USA \\ * Correspondence: assari@umich.edu; Tel.: +1-734-232-0445; Fax: +1-734-615-8739
}

Received: 16 July 2018; Accepted: 26 September 2018; Published: 30 September 2018

\begin{abstract}
Background: Gender may alter African Americans' vulnerability to discrimination. The type of outcomes that follow exposure to discrimination may also be gender-specific. Although teacher discrimination is known to deteriorate school performance, it is yet unknown whether male and female African American youth differ in the effect of teacher discrimination on school performance. Objective: This cross-sectional study explored the moderating role of gender on the effect of teacher discrimination on school performance in a national sample of African American youth. Methods: The National Survey of American Life-Adolescent Supplement (NSAL-A) enrolled a nationally representative sample $(n=810)$ of $13-17$-year-old African American youth. Demographic factors, socioeconomic status, teacher discrimination, and school performance (grade point average, GPA) were measured. Linear multivariable regression models were applied for data analysis. Results: Males and females reported similar levels of perceived teacher discrimination. In the pooled sample, higher teacher discrimination was associated with lower school performance among African American youth $(b=-0.35 ; 95 \%$ confidence interval $(\mathrm{CI})=-0.49$ to -0.22$)$. Gender interacted with perceived teacher discrimination $(b=12 ; 95 \% \mathrm{CI}=0.24-2.02)$, suggesting a significant difference between males and females in the magnitude of the association between perceived teacher discrimination and GPA. In stratified models, perceived teacher discrimination was associated with worse school performance of females $(b=-12 ; 95 \% \mathrm{CI}=-0.03$ to -2.78$)$ but not males $(b=0.01$; $95 \% \mathrm{CI}=-0.07$ to 0.08$)$. Conclusion: In line with previous studies, gender was found to alter the vulnerability of African American youth to perceived discrimination. African American boys and girls may differ in their sensitivity to the effects of teacher discrimination on school performance.
\end{abstract}

Keywords: population groups; ethnic groups; race; ethnicity; racism; discrimination; Blacks; African Americans; gender; bias; teacher discrimination

\section{Introduction}

Perceived racial discrimination is a common experience across US institutions and systems [1-4], and is a main contributor to the racial and ethnic gap in well-being of Americans [5-13]. Perceived discrimination is a well-established risk factor for multiple physical and mental health outcomes [14-17], and evokes a wide range of undesired outcomes [9,18-27]. Perceived discrimination is linked to negative emotions [18] such as depression, anxiety, and distress [18-21], behavioral risk factors such as suicide [23], substance use [9,24-27], and obesity [28], hyper-vigilance [29], and social isolation [22]. Perceived teacher discrimination (PTD) is also a predictor of poor school performance defined as low grade point average (GPA) $[30,31]$ and school dropout $[32,33]$. 
Although all age groups of African Americans report perceived discrimination [29,34-38], African American youth who start developing their social and racial identity may perceive more discrimination [36-38]. Among African Americans, gender affects both perception as well as sensitivity to discrimination [30,31]. Minority males report more discrimination than minority females, a pattern which is shown in African American and other ethnic groups [27,36,39-41]. Gender also alters the harmful effects of discrimination [19,42-44], with females being more prone to the effects of discrimination on obesity and eating disorders [45] and males being more prone to the effects of discrimination on psychological distress [21], anxiety/depression [20], and substance use [46]. Thus, exposure and sensitivity to discrimination are not merely shaped by race and ethnicity, but by the intersection of gender and race/ethnicity $[21,23,30,31,42,44,47]$. As each intersectional social group (e.g., race/ethnicity by gender groups) has a unique life history, values systems, expectations, support systems, attributions, and norms [48], causes and consequences of the very same discriminatory experiences may vary for them. African American males and females are not an exception in this regard. Similar patterns are also shown for other types of environmental stressors [19,42].

Although PTD is an important type of discrimination against African American youth [49], very limited knowledge exists regarding gender differences in the effects of PTD on school performance of African American youth [30,31]. While overall, youth with PTD report poor school performance [50], this effect may differ for boys and girls [30,31]. However, available studies have mostly used local samples $[30,31]$, leaving a gap in the knowledge that is generalizable to the US population. As a result, there is a need for studies that recruit a nationally representative sample of adolescents. In addition, there is a need for studies with large sample sizes, which generate statistical power to test moderations and mediations of PTD on youth outcomes (e.g., school performance).

To fill the gap on the effects of PTD on school performance among African American youth, we explored gender variation in the link between PTD and grade point average (GPA) in a national sample of African American youth. In line with the past literature on male-female differences in exposure and sensitivity to discrimination [30,31,47,51] and other types of stress [19,42], we expected an interaction between gender and discrimination. We expected a larger effect of PTD on GPA in males compared to females.

\section{Methods}

\subsection{Design and Setting}

This cross-sectional study used data from the National Survey of American Life-Adolescent Supplement (NSAL-A) [36,52] - a landmark national mental health survey of African American youth [53], conducted as part of the Collaborative Psychiatric Epidemiology Surveys (CPES) [54]. The NSAL-A is one of the very few available studies that makes a distinction between ethnic groups of Blacks. The NSAL (CPES) was conducted by the Institute for Social Research (ISR) at the University of Michigan (UM).

\subsection{Ethical Considerations}

The NSAL-A study protocol was approved (B03-00004038-R1) in the year 2003 by the University of Michigan (UM) Institutional Review Board (IRB). Youth provided assent. Youth legal guardians signed written informed consent.

\subsection{Participants and Sampling}

The analytical sample in the current study was 810 African American adolescents aged 13 to 17 years old. Detailed description of the NSAL sampling and methodology is published elsewhere [55]. Participants were limited to African American youth who resided in US territories at the time of survey. The NSAL-A study measured the race/ethnicity of the youth according to the self-assigned race/ethnicity of the adolescent's household. Parents who lived in the same households as youth 
self-identified themselves as African American, being defined as Blacks with no ancestral ties to any Caribbean countries.

The NSAL adolescent sample was drawn from the same households as the NSAL adult samples. The NSAL used a national probability sample of African American households that resided in the US. The NSAL households were screened for eligible youth who were living in the same household. Households with adolescents were randomly selected. When multiple eligible youth were living in the household, two adolescents were enrolled based on their gender.

\subsection{Interviews and Data Collection}

Interviews were all conducted in English, and took approximately $100 \mathrm{~min}$. The response rate of the NSAL-A was $80.5 \%$ for African American youth. About $82 \%$ and $18 \%$ of the interviews were in-person and by phone, respectively. Face-to-face interviews were conducted in the adolescents' homes. In-person interviews used computer-assisted personal interviews (CAPIs). CAPI-trained interviewers used computers to conduct interviews. CAPI is a preferred interview method when the questionnaires are complex and long [56].

\subsection{Measures and Variables}

Demographic information: The study included two demographic variables, namely age and gender. While age was operationalized as a continuous measure, ranging from 13 to 17 , gender was treated as a dichotomous factor (female as the reference category).

Family income: The only socioeconomic status (SES) indicator in this study was family income. Family income was asked from the parent and was imputed for missing data. Higher family income was indicative of higher SES.

Perceived teacher discrimination (PTD): The NSAL-A used the following three items to measure PTD. Questions focused on experiences that occurred during the past year in the interaction with teachers at school. Similar to the Everyday Discrimination Scale (EDS) [57], items assess chronic, subtle, routine, and daily discrimination (in contrast to major and overt events) $[15,58,59]$. The items were: (1) "Your teachers treat you with less respect than other students", (2) "Your teachers act as if they think you are not smart", and (3) "Your teachers act as if they are afraid of you". The response item for each question was on a six-level Likert scale ranging from 1 (never) to 6 (almost every day). A total score was calculated to reflect the frequency of PTD during the past year, ranging from 3 to 18 , with a higher score indicating more discrimination by the teachers $(\alpha=0.86)$.

GPA: The following single item was used to measure GPA- "What kind of grades (do/did) you usually get?" Responses were on a five-item response scale, including (1) Failing Grades; (2) Ds; (3) Cs; (4) Bs; and (5) As. GPA was operationalized as a continuous measure. A higher score reflected a better school performance.

\subsection{Statistical Analysis}

To adjust for the complex design of the NSAL-A, Stata 15.0 (Stata Corp., College Station, TX, USA) was used for data analysis. The NSAL-A sample lacks independence. Data were weighted to adjust for non-independence as well as the selection probabilities and non-response at the household and individual levels [15]. Taylor expansion approximation was used to re-calculate the design-based variance. Standard errors (SEs) reflect the study weights due to the complex sampling design. We reported frequency and mean (SEs). Missing data were imputed for family income. Sub-pop survey linear regression models were applied for multivariable analyses. In the linear regression models, self-reported grade-point-average was the outcome variable, PTD was the predictor variable, and age, gender, and family income were the covariates. In the first step, the association of interest was calculated in the overall sample of African American youth (Model 1). In the next step, the gender by PTD interaction term was added to the model (Model 2). At the last step, gender-specific models were run for females and males (Model 3 and Model 4). Unstandardized regression coefficients (b), 
their $95 \%$ confidence intervals (CIs), and $p$-values were reported. $p$-values smaller than 0.05 were considered significant.

\section{Results}

\subsection{Descriptive Statistics}

Table 1 provides a summary of the description of participating African American youth. Male and female African American youth did not differ in PTD. African American males reported lower GPA than African American females (Table 1).

Table 1. Descriptive statistics among African American youth by gender.

\begin{tabular}{|c|c|c|c|c|c|c|}
\hline \multirow{2}{*}{ Characteristics } & \multicolumn{2}{|c|}{ All } & \multicolumn{2}{|c|}{ Males } & \multicolumn{2}{|c|}{ Females } \\
\hline & Mean & $95 \%$ CI & Mean & $95 \%$ CI & Mean & $95 \% \mathrm{CI}^{\mathrm{b}}$ \\
\hline Age (years) * & 15.21 & $15.08-15.34$ & 14.80 & $14.59-15.01$ & 15.55 & $15.44-15.65$ \\
\hline Income $(\$ 1000) *$ & 0.58 & -8.08 to 9.25 & 1.77 & $\begin{array}{c}-7.23 \text { to } \\
10.77\end{array}$ & -0.40 & -8.92 to 8.11 \\
\hline $\begin{array}{c}\text { Perceived Teacher } \\
\text { Discrimination (PTD) }\end{array}$ & -0.01 & -0.12 to 0.09 & 0.04 & -0.10 to 0.19 & -0.07 & -0.19 to 0.05 \\
\hline $\begin{array}{l}\text { Grade Point Average } \\
\text { (GPA)* }\end{array}$ & 3.68 & $3.59-3.77$ & 3.50 & $3.39-3.61$ & 3.86 & $3.78-3.94$ \\
\hline
\end{tabular}

\subsection{Linear Multivariable Regression Models}

Table 2 shows the results of two linear multivariable regression models in the overall sample of African American youth, with PTD as the predictor variable, GPA as the outcome variable, and gender, age, and family income as the covariates. Model 1 only entered the main effects. Model 2, however, also included the gender by PTD interaction term.

In the overall sample of African American youth, PTD was associated with lower GPA $(b=-0.35$; $95 \% \mathrm{CI}=-0.49$ to -0.22$)$. Gender interacted with PTD $(b=12 ; 95 \% \mathrm{CI}=0.24-2.02)$, suggesting a significant difference in the magnitude of the association between PTD and GPA between male and female youth (Table 2).

\subsection{Stratified Linear Regression Models}

Table 3 shows a summary of the results for Model 3 and Model 4 which were estimated in females and males, respectively. In stratified models, PTD was associated with school performance for females $(b=-12 ; 95 \% \mathrm{CI}=-0.03$ to -2.78$)$ but not males $(b=0.01 ; 95 \% \mathrm{CI}=-0.07$ to 0.08$)$. (Table 3 ). 
Table 2. Linear multivariable regression models in the overall sample of African American youth.

\begin{tabular}{|c|c|c|c|c|c|c|c|c|c|c|c|c|}
\hline \multirow[t]{2}{*}{ Characteristics } & $b$ & SE & \multicolumn{2}{|c|}{$95 \% \mathrm{CI}$} & $t$ & $p$ & $b$ & SE & \multicolumn{2}{|c|}{$95 \% \mathrm{CI}$} & $t$ & $p$ \\
\hline & \multicolumn{6}{|c|}{ Model 1 (Main Effects) } & \multicolumn{6}{|c|}{ Model 1 (Interaction) } \\
\hline Gender (Male) & $-0.35^{* * *}$ & 0.07 & -0.49 & -0.22 & -5.36 & 0.000 & $-0.12 *$ & 0.04 & -0.21 & -0.03 & -2.74 & 0.011 \\
\hline $\begin{array}{c}\text { Perceived Teacher } \\
\text { Discrimination (PTD) }\end{array}$ & $-0.05 *$ & 0.02 & -0.10 & 0.00 & -2.18 & 0.038 & 0.02 & 0.02 & -0.03 & 0.06 & 0.77 & 0.447 \\
\hline Age & 0.02 & 0.02 & -0.02 & 0.06 & 0.88 & 0.388 & 0.00 & 0.00 & 0.00 & 0.00 & 1.69 & 0.101 \\
\hline Income & 0.00 & 0.00 & 0.00 & 0.00 & 1.64 & 0.113 & $-0.35^{* * *}$ & 0.06 & -0.48 & -0.22 & -5.44 & 0.000 \\
\hline $\begin{array}{c}\text { Gender (Male) }{ }^{*} \\
\text { Perceived Teacher } \\
\text { Discrimination (PTD) }\end{array}$ & - & - & - & - & - & - & 0.12 * & 0.06 & 0.00 & 0.24 & 2.02 & 0.050 \\
\hline Intercept & $3.58^{* * *}$ & 0.31 & 2.95 & 4.21 & 11.63 & 0.000 & $3.61^{* * *}$ & 0.30 & 2.99 & 4.24 & 11.86 & 0.000 \\
\hline
\end{tabular}

Outcome-grade point average (GPA); $b$-regression coefficient; ${ }^{*} p<0.05 ;{ }^{* *} p<0.01$; ${ }^{* * *} p<0.001$.

Table 3. Stratified linear regression models in female and male African American youth.

\begin{tabular}{|c|c|c|c|c|c|c|c|c|c|c|c|c|}
\hline \multirow[t]{2}{*}{ Characteristics } & $b$ & SE & \multicolumn{2}{|c|}{$95 \%$ CI } & $t$ & $p$ & $b$ & SE & \multicolumn{2}{|c|}{$95 \% \mathrm{CI}$} & $t$ & $p$ \\
\hline & \multicolumn{6}{|c|}{ Model 3 (Females) } & \multicolumn{6}{|c|}{ Model 4 (Males) } \\
\hline $\begin{array}{l}\text { Perceived Teacher } \\
\text { Discrimination }\end{array}$ & $-0.12^{* *}$ & 0.04 & -0.21 & -0.03 & -2.78 & 0.010 & 0.01 & 0.04 & -0.07 & 0.08 & 0.16 & 0.875 \\
\hline Age & 0.03 & 0.03 & -0.03 & 0.09 & 1.05 & 0.301 & 0.00 & 0.02 & -0.05 & 0.05 & 0.08 & 0.934 \\
\hline Income & 0.00 & 0.00 & 0.00 & 0.00 & 0.97 & 0.340 & 0.00 & 0.00 & 0.00 & 0.00 & 1.13 & 0.268 \\
\hline Intercept & $3.40^{* * *}$ & 0.42 & 2.54 & 4.26 & 8.12 & 0.000 & $3.47^{* * *}$ & 0.33 & 2.79 & 4.16 & 10.38 & 0.000 \\
\hline
\end{tabular}




\section{Discussion}

In a national sample of African American youth, the current study showed three major findings: First, males and females reported similar levels of PTD. Second, more PTD was associated with worse GPA among all youth. Third, PTD showed a larger effect on the school performance of females than males.

The findings were unexpected and different from previous studies that have shown stronger effects of discrimination on various outcomes for males than for females. Not many studies have found that girls are harmed to a greater extent by perceived discrimination than boys. Such differences may be in part due to the differences in context, design, sample, sampling, and other methodological aspects across studies.

Very few studies have compared boys and girls for the effect of discrimination on school outcomes of African American youth. In a unique study by Chavous et al. [31], 204 male and 206 female African American adolescents in Grades 8 and 11 were examined. The study showed gender differences in the impact of earlier and later peer discrimination experiences on academic outcomes. For boys but not girls, racial centrality was associated with better school performance. Additionally, boys and girls differed in the moderating effect of racial centrality on the relationship between discrimination and academic outcomes. For boys, higher racial centrality diminished the risk for lower school grades due to experiencing classroom discrimination. For girls, higher racial centrality was protective against the negative impact of peer discrimination on academic constructs. For girls, peer discrimination related positively to academic self-concept in the presence of low race-centrality. Girls and boys also differed in how SES moderated the relationship between perceived discrimination and academic outcomes. The authors suggested that interactions between individual- and contextual-level factors are needed to better understand the role of discrimination on the academic and social development of African American youths [31].

In our study, compared to boys, girls' school performance showed a larger negative effect due to teacher discrimination. Theories of gender socialization might help us to understand why gender may matter in the effects of social distress and social undermining on various developmental outcomes (e.g., PTD on school performance). Gender is a social construct, and shapes socialization and the differential impact of problematic social relations [60].

The higher sensitivity of girls' GPA to PTD may be in part because girls' school performance is better overall (more room for change due to PTD) [61]. Teachers' expectations are also higher for females than males [62], and thus any decline of these expectations may be more consequential for girls than boys. Another explanation is that girls more commonly engage and rely on the exchange of social support with other members of their social network [63-65]. Thus, poor quality of relationship with teachers (due to discrimination) may be more damaging to girls than to boys. The same is shown for supportive relations with parents in prior studies [66].

Social relations have differential effects on the socialization and outcomes of girls and boys [67]. The greater sensitivity of females compared to males to PTD is in line with research showing stronger impact of change in social relations on females than males [68]. However, the results are in contrast to previous studies that suggest males may be more sensitive to discrimination and other types of environmental stress on outcomes such as distress, depression, and substance use $[15,19,21,29,69]$.

A considerable body of literature suggests that gender [21], gender norms [41,48], socioeconomic status [26,69-73], racial identity [9,38,41,43,74,75], and racial attribution [43] change exposure and sensitivity to perceived discrimination. How ambiguous situations are interpreted depend on a wide range of traits and factors such as racial identity that shape the salience of race in day-by-day encounters [27,74]. Masculine ideologies may explain some of the observed findings regarding male gender sensitivity to discrimination $[41,48,59,75]$. Gender norms that shape beliefs about dominance and hierarchy may make males vulnerable to discrimination $[59,75,76]$. Males and females also differ in coping strategies and styles [41,77]. While males more frequently use confrontational coping [78], females more commonly use avoidant coping [77]. Compared to females, males more commonly act out their stress and emotions [79,80]. Males also do not use social supports in the same way as females [81]. 
African American families have major roles in shaping gender differences in sensitivity to discrimination [82,83]. African American parents differently deliver race socialization messages to their sons and daughters $[82,83]$. The effects of these messages may not be similar for boys and girls [84]. Male and female youth may also differ in peers' influences [85]. Messages from different sources may ultimately result in a wide range of gender differences in expectation and response to discrimination across settings including schools. Gender differences in socialization may contribute to gender-specific effects of discrimination. While African American parents often tend to provide more race-related messages to their sons than to their daughters [86,87], they should also recognize that their daughters are very vulnerable to PTD.

The finding that male and female African American youth report similar PTD was unexpected. Some theories and empirical reports suggest that males report high exposure to discrimination. The Subordinate Male Target hypothesis suggests that across all ethnic groups, males are subject to more discrimination than females [30]. Thus, social patterning of discrimination not only depends on race/ethnicity, but on the intersection of gender and race/ethnicity as well $[88,89]$. Thus, it is not the addition of social identities but the multiplication of them that is associated with exposure to discrimination, which is in line with the intersectionality framework [90-93].

Due to the racial profiling of African American males, African American males experience high levels of threat-based discrimination. Similar findings are reported for other ethnic groups, such as Arab Americans [21], Latinos [44], and Caribbean Blacks [46].

Gender should be regarded as a central construct for studying the effects of racism on child development [35]. In a cross-sectional study among Caribbean Black youth, perceived discrimination was more common among males with darker skin tones. However, skin color did not influence perceived discrimination among females [94]. In other longitudinal studies, male gender was a risk factor for an increase in perceived discrimination over an 18-year follow-up period [88,89].

While research has consistently documented discrimination in racial and ethnic minority populations, far less is known about specific sources of discrimination such as those in various settings and enacted by various perpetrators. In this study, we focused on a particular type of discrimination-teacher discrimination. In our study, African American males and females reported similar levels of discrimination by teachers. However, it was female not male youth who were sensitive to the effects of teacher discrimination on school performance. A large body of evidence shows gendered response to discrimination, but the outcomes that follow discrimination are specific to gender $[21,23,30,31,42,44,47]$.

Studies suggest that among various groups of racial and ethnic minorities, males are at a disadvantage in terms of exposure to discrimination as well as effects of discrimination on depression, distress, and substance use [19,27,36,39-44,88,89]. Despite existing policies [95], African American males and females are commonly target of discrimination by institutions such as the educational system, police, the correctional system, as well as the labor market [95]. Teachers also commonly discriminate against African American male and female students [30,31].

Although we did not find a main effect of gender on PTD, the media portrays African American males and females differently. That is, the media shapes different stereotypes against African American boys and girls in the minds of Americans, including teachers. The US media portrays African American males as aggressive and anti-intellectual $[40,41,96,97]$ and African American females as sexual [98]. African American males have been stereotyped as "endangered, aggressive, angry, superhuman, subhuman, lazy, hyperactive, jailed, and paroled, on probation, lost, loveless, incorrigible, or just simply self-destructive" $[99,100]$. These stereotypes particularly evoke discrimination against African Americans [94].

Among African Americans, discrimination and other environmental stressors may have gender-specific effects, with females developing obesity and eating disorders [45] while males develop substance use and depression $[44,96,97,101]$. Discrimination has stronger effects on psychological distress [21], depressive and anxiety symptoms [19,20], and major depressive disorder (MDD) [101] 
for males than females. This study extends the current knowledge by showing that females may be more sensitive to the effects of PTD on school performance.

\subsection{Limitations}

The current study is not free from methodological limitations. First, the data were old-the data were collected 15 years ago. Still, the NSAL-A is one of the very few nationally representative data sets that are available on African American youth. This study failed to include relevant measures such as attribution, vigilance, personality, identity, and coping that may explain gender differences in the effect of discrimination on various outcomes. We also did not include contextual data from school (e.g., \% whites and Blacks at school). The study also failed to collect data on teachers (age, gender, race). Such data could help in clarifying the discrimination pattern. In addition, we did not have any information on the type of school or socioeconomic status of school. The validity of self-reported GPA is well-documented. As a result, despite the limitation in the outcome measurement, this paper still makes a unique contribution to the literature, given the established validity of the outcome variable. Despite these limitations, recruiting a nationally representative sample of African American youth with a large sample size should be regarded as a strength of this study. Our findings contribute to the literature on gender differences in child and academic development [61,102-104] among African Americans.

\subsection{Implications}

All types of discrimination are inhumane [105], as they devalue individuals and diminish peoples' sense of dignity and pride [106,107]. On top of such profound effects on self-esteem [108], perceived discrimination has other detrimental effects on a wide range of undesired and negative effects on health, well-being, and development [5-7,29,34-38]. There are already multiple legislations, laws, and regulations that ban discrimination in all settings [95]. The main problem is not a lack of laws, but that they are not enforced enough [109]. Instead of new policies, there is a need to reinforce existing laws.

Although schools are one of the main contexts for adolescent development [110], they are not the only locations where African American youth are discriminated against. Teacher discrimination should be seen in line with several other systems and institutions that unjustly treat African Americans. African American males disproportionately become targets of police brutality, mass incarceration, and stop and frisk policies and practices [111-114]. Systems such as school, police, and correctional settings need to introduce new trainings in their system to reduce blunt reactions toward African American youth, particularly those with larger body sizes and darker skin colors [94]. The same may apply to schools, teachers, and principals, who can discriminate against African American youth [115-117]. Teacher discrimination may increase the risk of drop out and suspension [118-121], as well as school performance.

Several measures and interventions can be used to decrease discrimination by school authorities. Increasing the diversity of the teacher pool is one step. White teachers should receive training to reduce implicit and explicit bias against African American students. Schools should receive a specific budget to educate school personnel on bias, racism, prejudice, and discrimination. Schools may make diversity a priority. Zero tolerance for discrimination may also be a step toward reducing the unfair treatment of African American students. Other initiatives with the potential to reduce teacher discrimination should be also explored.

\subsection{Future Research}

There is a need for studies that decompose actual and enacted discrimination from those which are merely perceived. Research needs to study how gender shapes attribution, vigilance, and identity related to race and ethnicity. There is also a need to study how the development of gender norms shapes experiences of discrimination due to other social identities. Future research should also test how gender is a determinant of actual discrimination by teachers against African American youth. Additional research 
that uses longitudinal data with multiple observations is needed. Finally, studies should explore whether males' increased sensitivity to discrimination is due to long-term chronic exposure to discrimination that alters vigilance, racial identity, and coping, or is actually enacted by teachers and principals.

\section{Conclusions}

Similar to the previous studies on gender differences in exposure and vulnerability to discrimination $[19,27,36,39-44]$, the current study revealed gender differences in the effects of teacher discrimination on GPA among African American youth. Being generalizable to the US population, the results suggest that among African American youth, teacher discrimination is common in both males and females, but such discrimination may be a more salient determinant of school performance for females than males. There is a need to reduce racism and discrimination for both genders and at all levels. Programs that reduce teacher discrimination at schools may differently impact the school performance of male and female African American youth.

Author Contributions: The original idea of this analysis was developed by S.A., who also analyzed the data and drafted the paper. C.H.C. was the co-principal investigator of the NSAL-A and contributed to data collection, interpretation of the results, and revisions. Data were downloaded from the University of Michigan ICPSR.

Funding: The NSAL is mostly supported by the National Institute of Mental Health (NIMH), with grant U01-MH57716. Other support came from the Office of Behavioral and Social Science Research at the National Institutes of Health and the University of Michigan. James Jackson was the principal investigator of the NSAL-A. Cleopatra Caldwell is the co-principle investigator of the NSAL-A. Shervin Assari is partially funded by the UCLA BRITE Center which is funded by the National Institute on Minority Health and Health Disparities (4P60MD006923-05; PI = Vickie Mays).

Conflicts of Interest: The author declares no conflict of interest.

\section{References}

1. Hagiwara, N.; Dovidio, J.F.; Eggly, S.; Penner, L.A. The effects of racial attitudes on affect and engagement in racially discordant medical interactions between non-Black physicians and Black patients. Group Process. Intergr. Relat. 2016, 19, 509-527. [CrossRef] [PubMed]

2. Hagiwara, N.; Slatcher, R.B.; Eggly, S.; Penner, L.A. Physician racial bias and word use during racially discordant medical interactions. Health Commun. 2017, 32, 401-408. [CrossRef] [PubMed]

3. Penner, L.A.; Blair, I.V.; Albrecht, T.L.; Dovidio, J.F. Reducing racial health care disparities: A social psychological analysis. Policy Insights Behav. Brain Sci. 2014, 1, 204-212. [CrossRef] [PubMed]

4. Penner, L.A.; Dovidio, J.F.; Gonzalez, R.; Albrecht, T.L.; Chapman, R.; Foster, T.; Harper, F.W.; Hagiwara, N.; Hamel, L.M.; Shields, A.F.; et al. The effects of oncologist implicit racial bias in racially discordant oncology interactions. J. Clin. Oncol. 2016, 34, 2874-2880. [CrossRef] [PubMed]

5. Brown, T.N.; Williams, D.R.; Jackson, J.S.; Neighbors, H.W.; Torres, M.; Sellers, S.L.; Brown, K.T. “Being black and feeling blue": The mental health consequences of racial discrimination. Race Soc. 2000, 2, 117-131. [CrossRef]

6. Canady, R.B.; Bullen, B.L.; Holzman, C.; Broman, C.; Tian, Y. Discrimination and symptoms of depression in pregnancy among African American and White women. Women Health Issues 2008, 18, 292-300. [CrossRef] [PubMed]

7. Foynes, M.M.; Shipherd, J.C.; Harrington, E.F. Race and gender discrimination in the Marines. Cult. Divers. Ethn. Minor. Psychol. 2013, 19, 111-119. [CrossRef] [PubMed]

8. Odom, E.C.; Vernon-Feagans, L. Buffers of racial discrimination: Links with depression among rural African American mothers. J. Marriage Fam. 2010, 72, 346-359. [CrossRef] [PubMed]

9. Pascoe, E.A.; Smart Richman, L. Perceived discrimination and health: A meta-analytic review. Psychol. Bull. 2009, 135, 531-554. [CrossRef] [PubMed]

10. Schulz, A.J.; Gravlee, C.C.; Williams, D.R.; Israel, B.A.; Mentz, G.; Rowe, Z. Discrimination, symptoms of depression, and self-rated health among African American women in Detroit: Results from a longitudinal analysis. Am. J. Public Health 2006, 96, 1265-1270. [CrossRef] [PubMed]

11. Torres, L.; Ong, A.D. A daily diary investigation of latino ethnic identity, discrimination, and depression. Cult. Divers. Ethn. Minor. Psychol. 2010, 16, 561-568. [CrossRef] [PubMed] 
12. Wagner, J.; Abbott, G. Depression and depression care in diabetes relationship to perceived discrimination in African Americans. Diabetes Care 2007, 30, 364-366. [CrossRef] [PubMed]

13. Walker, R.L.; Salami, T.K.; Carter, S.E.; Flowers, K. Perceived racism and suicide ideation: Mediating role of depression but moderating role of religiosity among African American adults. Suicide Life-Threat. Behav. 2014, 44, 548-559. [CrossRef] [PubMed]

14. Banks, K.H.; Kohn-Wood, L.P.; Spencer, M. An examination of the African American experience of everyday discrimination and symptoms of psychological distress. Community Ment. Health J. 2006, 42, 555-570. [CrossRef] [PubMed]

15. Brondolo, E.; Ver Halen, N.B.; Pencille, M.; Beatty, D.; Contrada, R.J. Coping with racism: A selective review of the literature and a theoretical and methodological critique. J. Behav. Med. 2009, 32, 64-88. [CrossRef] [PubMed]

16. Ong, A.D.; Fuller-Rowell, T.; Burrow, A.L. Racial discrimination and the stress process. J. Personal. Soc. Psychol. 2009, 96, 1259-1271. [CrossRef] [PubMed]

17. Utsey, S.O.; Giesbrecht, N.; Hook, J.; Stanard, P.M. Cultural, sociofamilial, and psychological resources that inhibit psychological distress in African Americans exposed to stressful life events and race-related stress. J. Couns. Psychol. 2008, 55, 49-62. [CrossRef]

18. Himmelstein, M.S.; Young, D.M.; Sanchez, D.T.; Jackson, J.S. Vigilance in the discrimination-stress model for Black Americans. Psychol. Health 2015, 30, 253-267. [CrossRef] [PubMed]

19. Assari, S.; Smith, J.R.; Caldwell, C.H.; Zimmerman, M.A. Gender differences in longitudinal links between neighborhood fear, parental support, and depression among African American emerging adults. Societies 2015, 5, 151-170. [CrossRef]

20. Assari, S.; Moazen-Zadeh, E.; Caldwell, C.H.; Zimmerman, M.A. Racial discrimination during adolescence predicts mental health deterioration in adulthood: Gender differences among blacks. Front. Public Health 2017, 5, 104. [CrossRef] [PubMed]

21. Assari, S.; Lankarani, M.M. Discrimination and psychological distress: Gender differences among Arab Americans. Front. Psychiatry 2017, 8, 23. [CrossRef] [PubMed]

22. Broudy, R.; Brondolo, E.; Coakley, V.; Brady, N.; Cassells, A.; Tobin, J.N.; Sweeney, M. Perceived ethnic discrimination in relation to daily moods and negative social interactions. J. Behav. Med. 2007, 30, 31-43. [CrossRef] [PubMed]

23. Assari, S.; Caldwell, C.H. Discrimination and suicidal ideation among black adolescents. Behav. Sci. 2017, 7, 75. [CrossRef] [PubMed]

24. Visser, M.J.; Ikram, U.Z.; Derks, E.M.; Snijder, M.B.; Kunst, A.E. Perceived ethnic discrimination in relation to smoking and alcohol consumption in ethnic minority groups in The Netherlands: The HELIUS study. Int. J. Public Health 2017, 62, 879-887. [CrossRef] [PubMed]

25. Gilbert, P.A.; Zemore, S.E. Discrimination and drinking: A systematic review of the evidence. Soc. Sci. Med. 2016, 161, 178-194. [CrossRef] [PubMed]

26. Otiniano Verissimo, A.D.; Gee, G.C.; Ford, C.L.; Iguchi, M.Y. Racial discrimination, gender discrimination, and substance abuse among Latina/os nationwide. Cult. Divers. Ethn. Minor. Psychol. 2014, 20, 43-51. [CrossRef] [PubMed]

27. Sellers, R.M.; Shelton, J.N. The role of racial identity in perceived racial discrimination. J. Personal. Soc. Psychol. 2003, 84, 1079-1092. [CrossRef]

28. Sutin, A.R.; Terracciano, A. Perceived weight discrimination and obesity. PLoS ONE 2013, 8, e70048. [CrossRef] [PubMed]

29. Brondolo, E.; Brady, N.; Thompson, S.; Tobin, J.N.; Cassells, A.; Sweeney, M.; Contrada, R.J. Perceived racism and negative affect: Analyses of trait and state measures of affect in a community sample. J. Soc. Clin. Psychol. 2008, 27, 150-173. [CrossRef] [PubMed]

30. Ifatunji, M.A.; Harnois, C.E. An Explanation for the gender gap in perceptions of discrimination among African Americans considering the role of gender bias in measurement. Sociol. Race Ethn. 2015, 2, 263-288. [CrossRef]

31. Chavous, T.M.; Rivas-Drake, D.; Smalls, C.; Griffin, T.; Cogburn, C. Gender matters, too: The influences of school racial discrimination and racial identity on academic engagement outcomes among African American adolescents. Dev. Psychol. 2008, 44, 637-654. [CrossRef] [PubMed]

32. Felice, L.G. Black student dropout behavior: Disengagement from school rejection and racial discrimination. J. Negro Educ. 1981, 50, 415-424. [CrossRef] 
33. Mensch, B.S.; Kandel, D.B. Dropping out of high school and drug involvement. Sociol. Educ. 1988, 61, $95-113$. [CrossRef]

34. McLaughlin, K.A.; Hatzenbuehler, M.L.; Keyes, K.M. Responses to discrimination and psychiatric disorders among Black, Hispanic, female, and lesbian, gay, and bisexual individuals. Am. J. Public Health 2010, 100, 1477-1484. [CrossRef] [PubMed]

35. Williams, D.R.; Mohammed, S.A. Discrimination and racial disparities in health: Evidence and needed research. J. Behav. Med. 2009, 32, 20-47. [CrossRef] [PubMed]

36. Seaton, E.K.; Caldwell, C.H.; Sellers, R.M.; Jackson, J.S. The prevalence of perceived discrimination among African American and Caribbean Black youth. Dev. Psychol. 2008, 44, 1288-1297. [CrossRef] [PubMed]

37. Seaton, E.K.; Caldwell, C.H.; Sellers, R.M.; Jackson, J.S. An intersectional approach for understanding perceived discrimination and psychological well-being among African American and Caribbean Black youth. Dev. Psychol. 2010, 46, 1372-1379. [CrossRef] [PubMed]

38. Seaton, E.K.; Neblett, E.W.; Upton, R.D.; Hammond, W.P.; Sellers, R.M. The moderating capacity of racial identity between perceived discrimination and psychological well-being over time among African American youth. Child Dev. 2011, 82, 1850-1867. [CrossRef] [PubMed]

39. Coll, C.G.; Crnic, K.; Lamberty, G.; Wasik, B.H.; Jenkins, R.; Garcia, H.V.; McAdoo, H.P. An integrative model for the study of developmental competencies in minority children. Child Dev. 1996, 67, 1891-1914. [CrossRef]

40. Cunningham, M. African American adolescent males' perceptions of their community resources and constraints: A longitudinal analysis. J. Community Psychol. 1999, 27, 569-588. [CrossRef]

41. Swanson, D.P.; Cunningham, M.; Spencer, M.B. Black males' structural conditions, achievement patterns, normative needs, and "opportunities". Urban Educ. 2003, 38, 608-633. [CrossRef]

42. Assari, S.; Lankarani, M.M. Association between stressful life events and depression; intersection of race and gender. J. Racial Ethn. Health Dispar. 2016, 3, 349-356. [CrossRef] [PubMed]

43. Assari, S.; Watkins, D.C.; Caldwell, C.H. Race attribution modifies the association between daily discrimination and major depressive disorder among blacks: The role of gender and ethnicity. J. Racial Ethn. Health Dispar. 2015, 2, 200-210. [CrossRef] [PubMed]

44. Brodish, A.B.; Cogburn, C.D.; Fuller-Rowell, T.E.; Peck, S.; Malanchuk, O.; Eccles, J.S. Perceived racial discrimination as a predictor of health behaviors: The moderating role of gender. Race Soc. Probl. 2011, 3, 160-169. [CrossRef] [PubMed]

45. Assari, S. Perceived Discrimination and Binge Eating Disorder; Gender Difference in African Americans. J. Clin. Med. 2018, 7, 89. [CrossRef] [PubMed]

46. Assari, S.; Mistry, R.; Caldwell, C.H. Perceived Discrimination and Substance Use among Caribbean Black Youth; Gender Differences. Brain Sci. 2018, 8, 131. [CrossRef] [PubMed]

47. Assari, S. Interaction Between Race and Gender on Implicit Racial Bias Against Blacks. Int. J. Epidemiol. Res. 2018, 5, 43-49. [CrossRef]

48. Caldwell, C.H.; Antonakos, C.L.; Tsuchiya, K.; Assari, S.; De Loney, E.H. Masculinity as a moderator of discrimination and parenting on depressive symptoms and drinking behaviors among nonresident African-American fathers. Psychol. Men Masc. 2013, 14, 47-58. [CrossRef]

49. Rosenbloom, S.R.; Way, N. Experiences of discrimination among African American, Asian American, and Latino adolescents in an urban high school. Youth Soc. 2004, 35, 420-451. [CrossRef]

50. Allen, W. Gender and Campus Race Differences in Black Student Academic Performance, Racial Attitudes and College Satisfaction; Southern Education Foundation: Atlanta, GA, USA, 1986.

51. Browne, I.; Misra, J. The intersection of gender and race in the labor market. Annu. Rev. Sociol. 2003, 29, 487-513. [CrossRef]

52. Taylor, J.Y.; Caldwell, C.H.; Baser, R.E.; Faison, N.; Jackson, J.S. Prevalence of eating disorders among Blacks in the National Survey of American Life. Int. J. Eat. Disord. 2007, 40, 10-14. [CrossRef] [PubMed]

53. Jackson, J.S.; Torres, M.; Caldwell, C.H.; Neighbors, H.W.; Nesse, R.M.; Taylor, R.J.; Trierweiler, S.J.; Williams, D.R. The National Survey of American Life: A study of racial, ethnic and cultural influences on mental disorders and mental health. Int. J. Methods Psychiatr. Res. 2004, 13, 196-207. [CrossRef] [PubMed]

54. Heeringa, S.G.; Wagner, J.; Torres, M.; Duan, N.; Adams, T.; Berglund, P. Sample designs and sampling methods for the Collaborative Psychiatric Epidemiology Studies [CPES]. Int. J. Methods Psychiatr. Res. 2004, 13, 221-240. [CrossRef] [PubMed] 
55. Baynes, L.M. If it's not black and white anymore, why does darkness cast a longer discriminatory shadow than lightness-an investigation and analysis of the color hierarchy. Denver Univ. Law Rev. 1997, 75, 131.

56. Squires, J.E.; Hutchinson, A.M.; Bostrom, A.M.; Deis, K.; Norton, P.G.; Cummings, G.G.; Estabrooks, C.A. A data quality control program for computer-assisted personal interviews. Nurs. Res. Pract. 2012, $2012,8$. [CrossRef] [PubMed]

57. Williams, D.R.; Yu, Y.; Jackson, J.S.; Anderson, N.B. Racial differences in physical and mental health: Socio-economic status, stress and discrimination. J. Health Psychol. 1997, 2, 335-351. [CrossRef] [PubMed]

58. Costas, R., Jr.; Garcia-Palmieri, M.R.; Sorlie, P.; Hertzmark, E. Coronary heart disease risk factors in men with light and dark skin in Puerto Rico. Am. J. Public Health 1981, 71, 614-619. [CrossRef] [PubMed]

59. Clark, R.; Coleman, A.P.; Novak, J.D. Brief report: Initial psychometric properties of the everyday discrimination scale in black adolescents. J. Adolesc. 2004, 27, 363-368. [CrossRef] [PubMed]

60. Brown, G.W.; Harris, T. Social Origins of Depression: A Study of Psychiatric Disorder in Women; Routledge: New York, NY, USA, 2012.

61. Duckworth, A.L.; Seligman, M.E. Self-discipline gives girls the edge: Gender in self-discipline, grades, and achievement test scores. J. Educ. Psychol. 2006, 98, 198. [CrossRef]

62. Auwarter, A.E.; Aruguete, M.S. Effects of student gender and socioeconomic status on teacher perceptions. J. Educ. Res. 2008, 101, 242-246. [CrossRef]

63. Vaux, A. Variations in social support associated with gender, ethnicity, and age. J. Soc. Issues 1985, 41, 89-110. [CrossRef]

64. Belle, D. Gender differences in the social moderators of stress. In Stress and Coping: An Anthology; Monat, A., Lazarus, R.S., Eds.; Columbia University Press: New York, NY, USA, 1991; pp. 258-274.

65. Wood, W.; Eagly, A.H. A cross-cultural analysis of the behavior of women and men: Implications for the origin of sex differences. Psychol. Bull. 2002, 128, 699-727. [CrossRef] [PubMed]

66. Leaper, C.; Anderson, K.J.; Sanders, P. Moderators of gender effects on parents' talk to their children: A meta-analysis. Dev. Psychol. 1998, 34, 3-27. [CrossRef] [PubMed]

67. Dumka, L.E.; Gonzales, N.A.; Bonds, D.D.; Millsap, R.E. Academic success of Mexican origin adolescent boys and girls: The role of mothers' and fathers' parenting and cultural orientation. Sex Roles 2009, 60, 588. [CrossRef] [PubMed]

68. Walen, H.R.; Lachman, M.E. Social support and strain from partner, family, and friends: Costs and benefits for men and women in adulthood. J. Soc. Pers. Relat. 2000, 17, 5-30. [CrossRef]

69. Assari, S.; Caldwell, C.H. Neighborhood safety and major depressive disorder in a national sample of black youth; Gender by ethnic differences. Children 2017, 4, 14. [CrossRef] [PubMed]

70. Assari, S.; Preiser, B.; Caldwell, C.H. High Socioeconomic Status May Increase African American Youth Vulnerability to Discrimination. Children 2017. submitted for publication.

71. Assari, S.; Moghani Lankarani, M.; Caldwell, C.H.; Zimmerman, M.A. Fear of Neighborhood violence during adolescence predicts development of obesity a decade later: Gender differences among African Americans. Arch. Trauma Res. 2016, 5, e31475. [CrossRef] [PubMed]

72. Beatty Moody, D.L.; Waldstein, S.R.; Tobin, J.N.; Cassells, A.; Schwartz, J.C.; Brondolo, E. Lifetime racial/ethnic discrimination and ambulatory blood pressure: The moderating effect of age. Health Psychol. 2016, 35, 333-342. [CrossRef] [PubMed]

73. Hudson, D.L.; Bullard, K.M.; Neighbors, H.W.; Geronimus, A.T.; Yang, J.; Jackson, J.S. Are benefits conferred with greater socioeconomic position undermined by racial discrimination among African American men? J. Men's Health 2012, 9, 127-136. [CrossRef] [PubMed]

74. Sellers, R.M.; Linder, N.C.; Martin, P.M.; Lewis, R.L. Racial identity matters: The relationship between racial discrimination and psychological functioning in African American adolescents. J. Res. Adolesc. 2006, 16, 187-216. [CrossRef]

75. Smalls, C.; White, R.; Chavous, T.; Sellers, R. Racial ideological beliefs and racial discrimination experiences as predictors of academic engagement among African American adolescents. J. Black Psychol. 2007, 33, 299-330. [CrossRef]

76. Hammond, W.P. Taking it like a man: masculine role norms as moderators of the racial discriminationdepressive symptoms association among African American men. Am. J. Public Health 2012, 102, 232-241. [CrossRef] [PubMed] 
77. Thomas, A.J.; Witherspoon, K.M.; Speight, S.L. Gendered racism, psychological distress, and coping styles of African American women. Cult. Divers. Ethn. Minor. Psychol. 2008, 14, 307-314. [CrossRef] [PubMed]

78. Dressler, W.W.; Bindon, J.R.; Neggers, Y.H. John Henryism, gender, and arterial blood pressure in an African American community. Psychosom. Med. 1998, 60, 620-624. [CrossRef] [PubMed]

79. Kramer, M.D.; Krueger, R.F.; Hicks, B.M. The role of internalizing and externalizing liability factors in accounting for gender differences in the prevalence of common psychopathological syndromes. Psychol. Med. 2008, 38, 51-61. [CrossRef] [PubMed]

80. Verma, R.; Balhara, Y.P.; Gupta, C.S. Gender differences in stress response: Role of developmental and biological determinants. Ind. Psychiatry J. 2011, 20, 4-10. [PubMed]

81. Reevy, G.M.; Maslach, C. Use of social support: Gender and personality differences. Sex Roles 2001, 44, 437-459. [CrossRef]

82. Hughes, D.; Rodriguez, J.; Smith, E.P.; Johnson, D.J.; Stevenson, H.C.; Spicer, P. Parents' ethnic-racial socialization practices: A review of research and directions for future study. Dev. Psychol. 2006, 42, 747. [CrossRef] [PubMed]

83. Hughes, D.; Johnson, D. Correlates in children's experiences of parents' racial socialization behaviors. J. Marriage Fam. 2001, 63, 981-995. [CrossRef]

84. Ruiz-Ortiz, R.; Braza, P.; Carreras, R.; Muñoz, J.M. Differential effects of mother's and father's parenting on prosocial and antisocial behavior: Child sex moderating. J. Child Fam. Stud. 2017, 26, 2182-2190. [CrossRef]

85. Hoxby, C. Peer Effects in the Classroom: Learning from Gender and Race Variation; National Bureau of Economic Research (No. w7867); National Bureau of Economic: Cambridge, MA, USA, 2000.

86. Bowman, P.J.; Howard, C. Race-related socialization, motivation, and academic achievement: A study of Black youths in three-generation families. J. Am. Acad. Child Psychiatry 1985, 24, 134-141. [CrossRef]

87. Coard, S.I.; Wallace, S.A.; Stevenson, H.C., Jr.; Brotman, L.M. Towards culturally relevant preventive interventions: The consideration of racial socialization in parent training with African American families. J. Child Fam. Stud. 2004, 13, 277-293. [CrossRef]

88. Assari, S.; Gibbons, F.X.; Simons, R.L. Perceived Discrimination among Black Youth: An 18-Year Longitudinal Study. Behav. Sci. 2018, 8, 44. [CrossRef] [PubMed]

89. Assari, S.; Caldwell, C.H. Social determinants of perceived discrimination among black youth: Intersection of ethnicity and gender. Children 2018, 5, 24. [CrossRef] [PubMed]

90. Cole, E.R. Intersectionality and research in psychology. Am. Psychol. 2009, 64, 170. [CrossRef] [PubMed]

91. Burgess-Proctor, A. Intersections of race, class, gender, and crime: Future directions for feminist criminology. Fem. Criminol. 2006, 1, 27-47. [CrossRef]

92. Cho, S.; Crenshaw, K.W.; McCall, L. Toward a field of intersectionality studies: Theory, applications, and praxis. Signs 2013, 38, 785-810. [CrossRef]

93. Nash, J.C. Re-thinking intersectionality. Fem. Rev. 2008, 89, 1-15. [CrossRef]

94. Assari, S.; Caldwell, C.H. Darker Skin Tone Increases Perceived Discrimination among Male but Not Female Caribbean Black Youth. Children 2017, 4, 107. [CrossRef] [PubMed]

95. Assari, S.; Miller, R.J.; Taylor, R.J.; Mouzon, D.; Keith, V.; Chatters, L.M. Discrimination fully mediates the effects of incarceration history on depressive symptoms and psychological distress among African American men. J. Racial Ethn. Health Dispar. 2017, 5, 243-252. [CrossRef] [PubMed]

96. Chavous, T.; Harris, A.; Rivas, D.; Helaire, L.; Green, L. Racial stereotypes and gender in context: An examination of African American college student adjustment. Sex Roles 2004, 51, 1-16. [CrossRef]

97. Van Laar, C.; Sidanius, J. Social status and the academic achievement gap: A social dominance perspective. Soc. Psychol. Educ. 2001, 4, 235-258. [CrossRef]

98. Rosenthal, L.; Lobel, M. Stereotypes of Black American Women Related to Sexuality and Motherhood. Psychol. Women Q. 2016, 40, 414-427. [CrossRef] [PubMed]

99. Stevenson, H.C., Jr. Playing with Anger: Teaching Coping Skills to African American Boys through Athletics and Culture, 1st ed.; Praeger Publishers: Westport, CT, USA, 2003.

100. Murry, V.M.; Block, E.P.; Liu, N. Adjustment and developmental patterns of African American males: The roles of families, communities, and other contexts. In Boys and Men in African American Families; Springer: Cham, Switzerland, 2017; Volume 7, pp. 7-32. 
101. Cogburn, C.D.; Chavous, T.M.; Griffin, T.M. School-based racial and gender discrimination among African american adolescents: Exploring gender variation in frequency and implications for adjustment. Race Soc. Probl. 2011, 3, 25-37. [CrossRef] [PubMed]

102. Meece, J.L.; Glienke, B.B.; Burg, S. Gender and motivation. J. Sch. Psychol. 2006, 44, 351-373. [CrossRef]

103. Stobart, G.; Elwood, J.; Quinlan, M. Gender bias in examinations: How equal are the opportunities? Br. Educ. Res. J. 1992, 18, 261-276. [CrossRef]

104. Herbert, J.; Stipek, D. The emergence of gender differences in children's perceptions of their academic competence. J. Appl. Dev. Psychol. 2005, 26, 276-295. [CrossRef]

105. Krieger, N.; Smith, K.; Naishadham, D.; Hartman, C.; Barbeau, E.M. Experiences of discrimination: Validity and reliability of a self-report measure for population health research on racism and health. Soc. Sci. Med. 2005, 61, 1576-1596. [CrossRef] [PubMed]

106. Waldron, J. Dignity and defamation: The visibility of hate. Harv. Law Rev. 2009, 123, 1596.

107. Armenta, B.E.; Hunt, J.S. Responding to societal devaluation: Effects of perceived personal and group discrimination on the ethnic group identification and personal self-esteem of Latino/Latina adolescents. Group Process. Intergroup Relat. 2009, 12, 23-39. [CrossRef]

108. Umaña-Taylor, A.J.; Updegraff, K.A. Latino adolescents' mental health: Exploring the interrelations among discrimination, ethnic identity, cultural orientation, self-esteem, and depressive symptoms. J. Adolesc. 2007, 30, 549-567. [CrossRef] [PubMed]

109. Gillborn, D. Critical race theory and education: Racism and anti-racism in educational theory and praxis. Discourse 2006, 27, 11-32. [CrossRef]

110. Eccles, J.S.; Roeser, R.W. Schools as developmental contexts during adolescence. J. Res. Adolesc. 2011, 21, 225-241. [CrossRef]

111. Milner, A.N.; George, B.J.; Allison, D.B. Black and Hispanic men perceived to be large are at increased risk for police frisk, search, and force. PLoS ONE 2016, 11, e0147158. [CrossRef] [PubMed]

112. Thomas, A.; Caldwell, C.H.; Assari, S.; Jagers, R.J.; Flay, B. You do what you see: How witnessing physical violence is linked to violent behavior among male African American adolescents. J. Men Stud. 2016, 24, 185-207. [CrossRef]

113. Araujo-Dawson, B. Understanding the complexities of skin color, perceptions of race, and discrimination among Cubans, Dominicans, and Puerto Ricans. Hisp. J. Behav. Sci. 2015, 37, 243-256. [CrossRef]

114. Ross, C.T. A multi-level Bayesian analysis of racial bias in police shootings at the county-level in the United States, 2011-2014. PLoS ONE 2015, 10, e0141854. [CrossRef] [PubMed]

115. Gilbert, K.L.; Ray, R. Why police kill black males with impunity: Applying Public Health Critical Race Praxis [PHCRP] to address the determinants of policing behaviors and "justifiable" homicides in the USA. J. Urban Health 2016, 93, 122-140. [CrossRef] [PubMed]

116. Mays, V.M.; Johnson, D.; Coles, C.N.; Gellene, D.; Cochran, S.D. Using the science of psychology to target perpetrators of racism and race-based discrimination for intervention efforts: Preventing another Trayvon Martin tragedy. J. Soc. Action Couns. Psychol. 2013, 5, 11-36. [PubMed]

117. Oliver, M.B.; Jackson, R.L.; Moses, N.N.; Dangerfield, C.L. The face of crime: Viewers' memory of race-related facial features of individuals pictured in the news. J. Commun. 2004, 54, 88-104. [CrossRef]

118. Davis, J.E. Early schooling and academic achievement of African American males. Urban Educ. 2003, 38, 515-537. [CrossRef]

119. Honora, D.T. The relationship of gender and achievement to future outlook among African American adolescents. Adolescence 2002, 37, 301-316. [PubMed]

120. Noguera, P.A. The trouble with Black boys: The role and influence of environmental and cultural factors on the academic performance of African American males. Urban Educ. 2003, 38, 431-459. [CrossRef]

121. Roderick, M. What's happening to the boys? Early high school experiences and school outcomes among African American male adolescents in Chicago. Urban Educ. 2003, 38, 538-607. [CrossRef]

(C) 2018 by the authors. Licensee MDPI, Basel, Switzerland. This article is an open access article distributed under the terms and conditions of the Creative Commons Attribution (CC BY) license (http:/ / creativecommons.org/licenses/by/4.0/). 